Journal of Zhejiang University-SCIENCE B (Biomedicine \& Biotechnology) ISSN 1673-1581 (Print); ISSN 1862-1783 (Online)

www.zju.edu.cn/jzus; www.springerlink.com

E-mail: jzus@zju.edu.cn

\title{
Report:
}

\section{Forty years of the war against Ebola}

\author{
Lei $\mathrm{ZHANG}^{1}$, Hao $\mathrm{WANG}^{2}$ \\ $\left({ }^{1}\right.$ Tianjin International Joint Academy of Biomedicine, Tianjin 300457, \\ China) \\ $\left({ }^{2}\right.$ Department of Biophysics, Nankai University, Tianjin 300071, China) \\ E-mail: biotech@china.com; hwang@nankai.edu.cn \\ Received Aug. 12, 2014; Revision accepted Aug. 14, 2014 \\ Published online Aug. 18, 2014; Crosschecked Aug. 16, 2014
}

doi:10.1631/jzus.B1400222

Document code: A

CLC number: R183.7

Humans have been fighting against the Ebola virus disease (EVD) since its first outbreak in 1976 in southern Sudan and Yambuku in Zaire which lies on the Ebola River.

According to the data from the World Health Organization (WHO, 2014b), the first outbreak claimed 431 lives in 1976, and the disease awoke transiently in Sudan three years later and then disappeared for 15 years afterwards. Following that, large outbreaks appeared in 1995 in Zaire with 250 deaths of people, 2001-2002 in Uganda with 224 deaths, 2002-2003 in Congo with 128 deaths, and 2007 in Congo with 187 deaths.

In 2014, the most severe and complicated outbreak swept through the West African countries having already taken 1069 lives, with the situation seeming to be out of control. To date, there have been 15 outbreaks in Africa, which have caused 4362 infected cases and claimed 2659 lives.

The pandemics of Ebola show obvious independence from any season. Humans are generally susceptible to the Ebola virus without gender or age variation. The natural reservoir of the Ebola virus still remains unclear. During the past 40 years or so, the EVD disappeared after an outbreak in one region and erupted in another region without any warning. The difficulty in understanding the spreading pattern of Ebola was compared to that of the wave-particle duality of light.

CC Zhejiang University and Springer-Verlag Berlin Heidelberg 2014

\section{Ebola alert}

The Ebola virus is attacking people in West African countries, such as Guinea, Liberia, Nigeria, and Sierra Leone. At least 1069 people have been killed by the virus and 1848 have been infected since the current outbreak began in February 2014, making it the worst Ebola outbreak ever (WHO, 2014a).

Currently, there are no proven cures or vaccine available to prevent this infection, so supportive care for severely ill patients focuses on alleviating symptoms, such as fever, vomiting, and diarrhea, all of which can contribute to severe dehydration. No specific treatment is available.

Ebola is causing a great panic in West Africa. For maintaining their own health, some families are dumping their infected relatives in the street, out of fear, instead of sending them to an isolation ward. Moreover, because of rumors and conspiracies, many patients find ways to escape from the hospital. Ebola victims' bodies are either left to rot on the street or abandoned in their homes, which results in a huge risk for the spread of the EVD. It is the WHO's greatest concern that such a situation may rapidly allow loss of control in containing the spread of the EVD.

The toll is expected to soar, and Margaret CHAN, the Director-General of WHO, has stated that "It is moving faster than we can control." (Fig. 1). The WHO declared the Ebola epidemic a Public Health Emergency of International Concern on Aug. 8, 2014, its highest level of alert. It was advised that the outbreak in West Africa is an "extraordinary event" and a public health risk to other countries. A coordinated international response is deemed essential to stop and reverse the international spread of Ebola.

\section{The past and present state of the Ebola}

The EVD, formerly known as the Ebola hemorrhagic fever, is a severe, often fatal illness caused 


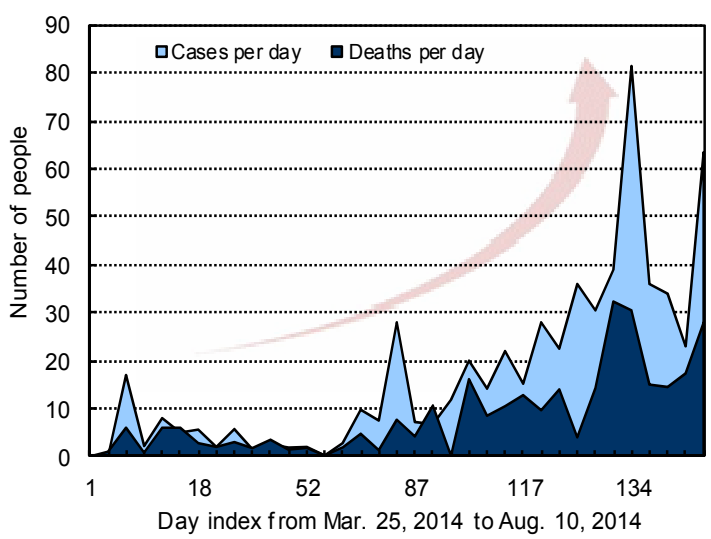

Fig. 1 Ebola cases and deaths per day as reported by WHO from Mar. 25, 2014 to Aug. 10, 2014

by the Ebola virus, which along with its sister, Marburg virus, unlike many other viruses, is thread-like in appearance (Johnson et al., 1977). The Ebola is transferrable from non-human animals to humans, and vice versa.

The name of the disease originates from one of the first recorded outbreaks in 1976 in Yambuku, the Democratic Republic of the Congo, which lies on the Ebola River, erupting simultaneously in 55 villages (Report of an International Commission, 1978). The strain of Ebola that broke out in Zaire has one of the highest fatality rates of any human virus, roughly $90 \%$ at that time.

There are five identified subtypes of the Ebola virus. Four subtypes have caused infection in humans: Ebola-Zaire, -Sudan, -Bundibugyo, and -Tai Forest. The fifth, Ebola-Reston, has caused infection in nonhuman primates, but not in humans to date. Mortality rates for the EVD range from $34 \%$ of the Bundibugyo subtype to $90 \%$ of the Zaire subtype, with death usually occurring as a result of shock rather than blood loss (Basler and Amarasinghe, 2009; Wamala et al., 2010).

The Ebola viruses are filamentous viruses with a negative-sense RNA genome. Virions are cylindrical/ tubular containing a viral envelope, matrix, and nucleocapsid components, approximately $80 \mathrm{~nm}$ in diameter and $800-1000 \mathrm{~nm}$ in length (Feldmann, 2014) (Fig. 2).

Humans are not the natural reservoir of the Ebola virus. They become infected when coming into close contact with Ebola-carrying animals, and then start transmitting the virus to other people. The origin of

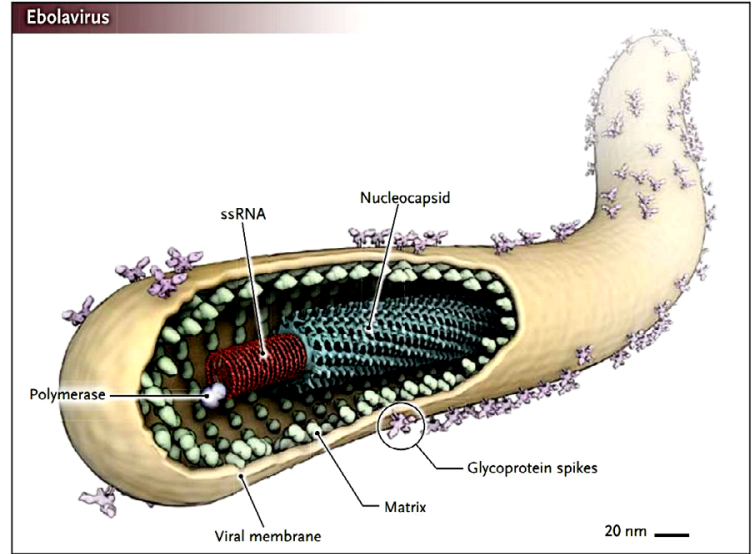

Fig. 2 Structure of the Ebola virus (Feldmann, 2014)

the virus is not known, bats are considered to be the most likely natural reservoir of the Ebola virus (Leroy et al., 2005). Bats are one major type of bush meat eaten by many Africans. Not only in rural communities but also in main towns in countries like Guinea, people consume a great amount of bush meat for protein; it is the indigenous people's tradition and banning bush meat is simply unrealistic. One can image that during hunting or food preparation, there are chances for the involved people being infected by the virus.

People become infected with the Ebola through close contact with infected animals, and the virus spreads person-to-person through contact with bodily fluids, such as blood or secretions, according to the WHO. Symptoms include fever, muscle pain, and headache, followed by vomiting, diarrhea, rash, and, in some cases, internal and external bleeding (WHO, 2014b).

The period of incubation for the Ebola virus hemorrhagic fever is usually $5-18 \mathrm{~d}$ but may extend from 2-21 d depending on the type of virus that one contacts. The Ebola virus acts quickly once infected and it essentially directs the human body's immune system into overdrive (Gupta et al., 2001). Initial symptoms of Ebola often resemble the symptoms of malaria, influenza, or various bacterial infections, all of which are more common than Ebola. It can often take too long for Ebola to be diagnosed, and by then the secondary symptoms may have set in: diarrhea, red eyes, vomiting blood, bleeding from the nose, mouth or rectum, and even bleeding in the brain. After these symptoms and going through a miserable 
week or so, patients either recover or die from a systemic multi-organ failure, often killing $50 \%-90 \%$ of those infected with the virus (WHO, 2014b).

Ebola is classified as a biosafety level 4 agent and is more contagious and lethal than human immunodeficiency virus (HIV). It is said that if we were able to concentrate the destructive effects to the human body of HIV in one year to one week, that would compare to the power of the Ebola virus. During the Cold War, the Ebola virus once was considered as a biological weapon.

To date, there have been 15 Ebola outbreaks during the past 40 years. The current one is the most complicated outbreak and has already caused a death toll surpassing the sum of all the past Ebola death tolls and the number is still growing (CDC, 2014) (Fig. 3).

\section{Why is there still no cure after almost 40 years?}

\section{Difficulty in identifying infection-related receptors}

Viruses are incapable of replicating on their own, what they do is inject their genome into a host cell; and when the host cell replicates, so does the virus. To accomplish its injecting job, the virus attaches to a protein, usually called a receptor, on the surface of the host cell. In fighting viruses, it is crucial to identify the virus' corresponding receptor, so you can prevent it from binding to host cells and thus prevent it from replicating. With the Ebola, this is the missing piece of the puzzle - we do not know what the receptor is! In humans, the Ebola is capable of invading many different kinds of host cells, making it a dangerous versatile aggressor (Kondratowicz et al., 2011; Miller et al., 2012).

\section{Rare virus draws little interest from funders}

Despite the media's fascination with Ebola, the disease is exceedingly rare, which has slowed the development of effective therapy. Before the current outbreak, all known outbreaks during the past three decades had claimed a little more than 2400 lives across 12 African countries. The financial situations of the affected countries do not allow them to develop their own countermeasures; most research has been funded by western governments in response to worries about bioterrorism (Reardon, 2014). Unfortunately, this support has not been sufficient enough to bring a single product to the market.

\section{Ongoing projects for fighting against the Ebola virus}

Although several vaccines and treatments for Ebola do exist, they are stalled in various stages of testing owing to a lack of funding and international demand. Even if they did move forward, it would be years, rather than months, before the measures would reach the people in need.

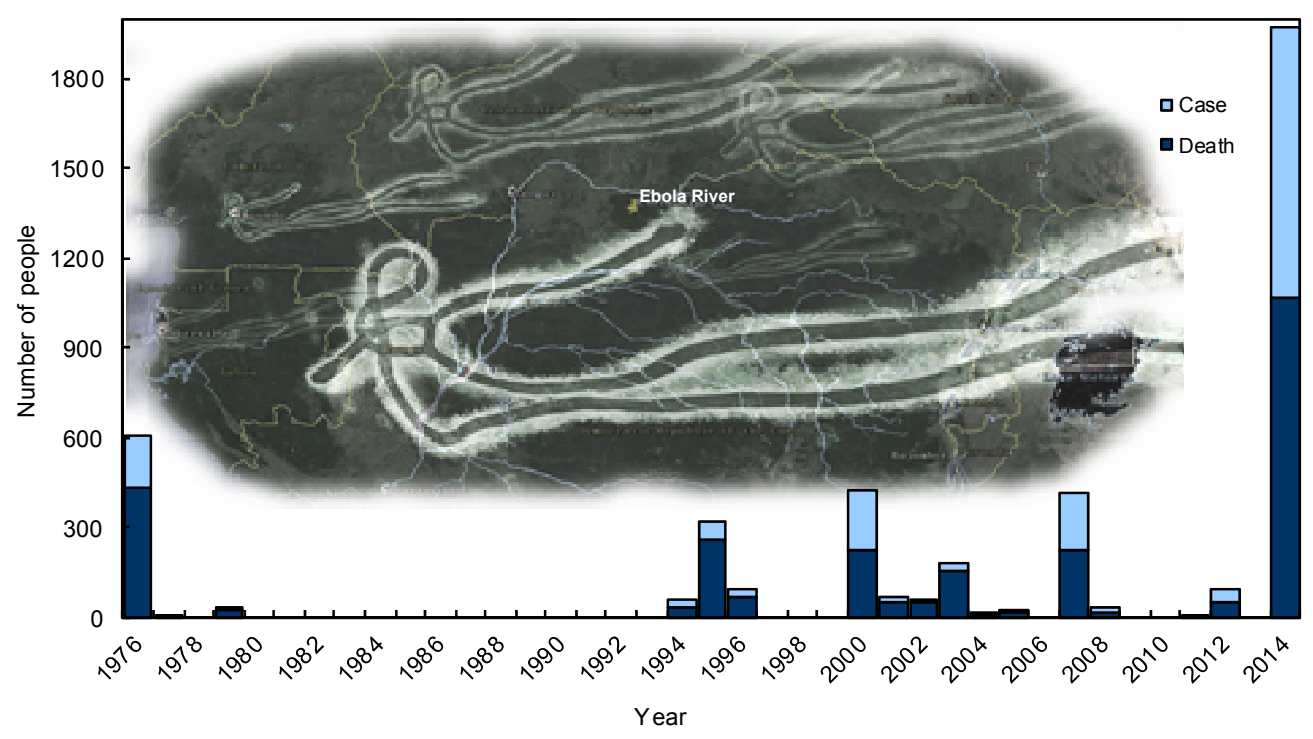

Fig. 3 Ebola virus disease outbreaks from 1976 


\section{Prevention: vaccine}

In 2005, Heinz FELDMANN, a virologist at the US National Institute of Allergy and Infectious Disease (NIAID) in Hamilton, Montana, published a vaccine platform based on the vesicular stomatitis virus that has since yielded an Ebola vaccine. The vaccine was proved to be effective in macaques (Geisbert et al., 2005). However, money is unavailable to take the next step on testing the vaccine's safety in healthy humans. The director of NIAID says that the institute is talking with the Food and Drug Administration (FDA) to speed up the approval process, a position that is strengthened by the current outbreak in West Africa.

\section{Potential treatments: antibody, interferon, RNA- interference drug, and survivor's serum}

Antibodies may be the best strategy for treating rare and deadly viruses such as Ebola, because they are effective even a few days after exposure. At present, an antibody "cocktail" is investigated as a potential cure for Ebola. In August 2013, Pettitt et al. (2013) reported that, $43 \%$ of infected monkeys recovered after being treated with MB-003, an antibody "cocktail", 4-5 d post-infection. Most recently, ZMapp was used to treat two American aid workers, which consists of three humanized monoclonal antibodies (Rastogi, 2014). Unfortunately, for safety concerns, the US regulatory agency refused to deploy the use of ZMapp in Africa.

The interferon $\alpha / \beta$ response is a major component of innate defense against virus infection. Viruses have evolved ways to inhibit the type I interferon production and responsiveness. So far animal studies have proved that the early post-exposure treatment with interferon $\beta$ significantly increased the survival time, but it failed to alter the mortality (Jahrling et al., 1999; Smith et al., 2013).

RNA-interference drug, identified by US army researchers and based on RNA interference, is in development at Tekmira Pharmaceuticals Co., a Canada-based company that has earned a contract with the US Department of Defense. In July 2014, however, Tekmira announced that the FDA had put a Phase I trial on hold because it wants more data and a change in the protocol to protect participants' safety (Tekmira Pharmaceuticals Co., 2014).

Ebola survivors' serum is full of naturallyproduced antibodies proven to be able to fight off the disease and therefore when transfused into an infected body, might help that body eliminate the Ebola itself.
In 1995, eight Ebola-infected patients in the Congo were transfused with blood donated by survivors. Only one transfused patient died; the fatality rate was significantly lower than the overall rate (Mupapa et al., 1999). Nevertheless, no public health organizations have considered the serum transfusion as a viable therapy for Ebola to date. The reason is two-fold: (1) A transfusion did not save Ebola-infected lives in several other human and animal-model studies, which shadowed the success of the 1999 report; (2) The efficacy of the transfusion therapy is essentially impossible to test, because Ebola only occasionally occurs but kills most infected people. Not enough blood can be collected during an outbreak for treating patients in the same outbreak.

\section{Prospect}

In desperate cases, any little sporadic flames could ignite the fire of hope. Currently, there are no licensed drugs or vaccines for the deadly EVD. Several drugs in various stages of development have caused widespread concern, especially ZMapp, which has resulted in significant improvement and is thought of as a miracle for two of the Ebola-infected Americans.

The FDA opened the "fast track" status for Ebola drugs, and an Ebola vaccine developed by GlaxoSmithKline obtained positive data in animal experiments, is currently undergoing Phase I clinical trials. Tekmira's TKM-Ebola also received FDA "verbally confirmed" changes on Aug. 9, 2014, which may allow the company to make the drug available.

However, it is unethical to apply unproven drugs to patients, and it also smacks of injustice that only American patients can try Ebola drugs such as ZMapp while the majority of patients in Africa are without trial drugs.

WHO is taking aggressive actions. On Aug. 11, 2014, WHO convened a consultation to consider and assess the ethical implications for clinical decisionmaking of the potential use of unregistered interventions. The panel reached consensus that in the particular circumstances of the current outbreak of EVD and provided certain conditions are met, it was ethical to offer unproven interventions with as yet unknown efficacy and adverse effects, as the potential treatment or prevention (WHO, 2014c). However, perhaps in the current circumstances with no cure for the virus, using of experimental drugs is the only option and the only hope. The first shipment of the experimental drug ZMapp arrived in Spain on Aug. 11, 2014. 


\section{Compliance with ethics guidelines}

Lei ZHANG and Hao WANG declare that they have no conflict of interest.

This article does not contain any studies with human or animal subjects performed by any of the authors.

\section{References}

Basler, C.F., Amarasinghe, G.K., 2009. Evasion of interferon responses by Ebola and Marburg viruses. J. Interferon Cytokine Res., 29(9):511-520. [doi:10.1089/jir.2009.0076]

CDC (US Centers for Disease Control and Prevention), 2014. Ebola outbreaks 2000-2014. Available from http://www. cdc.gov/vhf/ebola/resources/outbreaks.html [Accessed on Aug. 13, 2014].

Feldmann, H., 2014. Ebola-a growing threat? New Engl. J. Med., in press. [doi:10.1056/NEJMp1405314]

Geisbert, T.W., Jones, S., Fritz, E.A., et al., 2005. Development of a new vaccine for the prevention of Lassa fever. PLoS Med., 2(6):e183. [doi:10.1371/journal.pmed.0020183]

Gupta, M., Mahanty, S., Ahmed, R., 2001. Monocyte-derived human macrophages and peripheral blood mononuclear cells infected with Ebola virus secrete MIP- $1 \alpha$ and TNF- $\alpha$ and inhibit poly-IC-induced IFN- $\alpha$ in vitro. Virology, 284(1):20-25. [doi:10.1006/viro.2001.0836]

Jahrling, P.B., Geisbert, T.W., Geisbert, J.B., et al., 1999. Evaluation of immune globulin and recombinant interferon- $\alpha 2 b$ for treatment of experimental Ebola virus infections. J. Infect. Dis., 179(S1):S224-S234. [doi:10. 1086/514310]

Johnson, K.M., Lange, J.V., Webb, P.A., et al., 1977. Isolation and partial characterisation of a new virus causing acute haemorrhagic fever in Zaire. Lancet, 309(8011):569-571. [doi:10.1016/S0140-6736(77)92000-1]

Kondratowicz, A.S., Lennemann, N.J., Sinn, P.L., et al., 2011. T-cell immunoglobulin and mucin domain 1 (TIM-1) is a receptor for Zaire Ebolavirus and Lake Victoria Marburgvirus. PNAS, 108(20):8426-8631. [doi:10.1073/pnas. 1019030108]

Leroy, E.M., Kumulungui, B., Pourrut, X., et al., 2005. Fruit bats as reservoirs of Ebola virus. Nature, 438(7068): 575-576. [doi:10.1038/438575a]

Miller, E.H., Obernosterer, G., Raaben, M., et al., 2012. Ebola virus entry requires the host-programmed recognition of an intracellular receptor. EMBO J., 31(8):1947-1960. [doi:10.1038/emboj.2012.53]
Mupapa, K., Massamba, M., Kibadi, K., et al., 1999. Treatment of Ebola hemorrhagic fever with blood transfusions from convalescent patients. J. Infect. Dis., 179(S1): S18-S23. [doi:10.1086/514298]

Pettitt, J., Zeitlin, L., Kim, D.H., et al., 2013. Therapeutic intervention of Ebola virus infection in rhesus macaques with the MB-003 monoclonal antibody cocktail. Sci. Transl. Med., 5(199):199ra113. [doi:10.1126/scitranslmed. 3006608]

Rastogi, J., 2014. Canadians leading anti-Ebola research. Canad. Med. Assoc. J., in press. [doi:10.1503/cmaj.1094869]

Reardon, S., 2014. Ebola treatments caught in limbo. Nature, 511(7511):520. [doi:10.1038/511520a]

Report of an International Commission, 1978. Ebola haemorrhagic fever in Zaire, 1976. Bull. World Health Organ., 56(2):271-293.

Smith, M., Hensley, L.E., Geisbert, T.W., et al., 2013. Interferon- $\beta$ therapy prolongs survival in rhesus macaque models of Ebola and marburg hemorrhagic fever. J. Infect. Dis., 208(2):310-318. [doi:10.1093/infdis/jis921]

Tekmira Pharmaceuticals Co., 2014. Tekmira receives fast track designation from FDA for its anti-Ebola viral therapeutic. Available from http://investor.tekmirapharm. com/releasedetail.cfm?ReleaseID $=830680$ [Accessed on Aug. 12, 2014].

Wamala, J., Lukwago, L., Malimbo, M., et al., 2010. Ebola hemorrhagic fever associated with novel virus strain, Uganda, 2007-2008. Emerg. Infect. Dis., 16(7):10871092. [doi:10.3201/eid1607.091525]

WHO (World Health Organization), 2014a. Disease outbreak news. Available from http://www.who.int/csr/don/en/ [Accessed on Aug. 15, 2014].

WHO (World Health Organization), 2014b. Ebola virus disease. Fact sheet $\mathrm{N}^{\circ} 103$, updated April 2014. Available from http://www.who.int/mediacentre/factsheets/fs103/en/ [Accessed on Aug. 12, 2014].

WHO (World Health Organization), 2014c. Ethical considerations for use of unregistered interventions for Ebola virus disease (EVD). Available from http://www.who.int/ mediacentre/news/statements/2014/ebola-ethical-reviewsummary/en/ [Accessed on Aug. 13, 2014].

\section{中文概要:}

\section{本文题目：埃博拉之役四十年}

Forty years of the war against Ebola

本文概要: 埃博拉病毒疫情自 1976 年在苏丹南部和旧扎伊尔的埃博拉河地区初次爆发，三年后在苏丹同一地区小规模 复发一次后则沉寂了 15 年。1994 年在加蓬地区再次突然复苏, 至今在非洲多国已反复爆发 15 次, 造成了 4362 人感染， 2659 人死亡。2014 年，西非几内亚、利比里亚、尼日利亚和塞拉利昂爆发了历史上最严重和情况最 复杂的疫情, 局面失控。埃博拉病毒流行无明显的季节性, 人群普遍易感且无性别差异, 其天然宿主仍不确 定。近四十年，疫情在一个地区消散后不知何时会在另一个地区突然暴发，被形容为像光的波粒二象性一般 难以理解。由于埃博拉病毒对人体多器官普遍攻击而防范困难，加之开发病毒防治药物项目资金匮乏，人类 至今没有找到能有效对抗埃博拉疫情的预防及治疗措施。 